\section{Burj Khalife jako modelowy przykład smart building: budynek przyszłości czy teraźniejszość?}

Burj Khalife as a model example of smart building: an edifice of tomorrow, or of the present?

\section{Streszczenie}

Pojęcie budynku inteligentnego ksztattowało się przez ostatnie 20-30 lat ubiegłego wieku. Początkowo pojęcie to odnosito sie jedynie do poziomu technicznego zaawansowania technologii zainstalowanych w budynku. Wraz z rozwojem społeczeństwa informatycznego, nowych form pracy, pojawiły się nowe wymagania w stosunku do budynku obejmujące, oprócz jakości technicznej, także jakość przestrzeni życia i pracy człowieka .

Wysokie wymagania dla budynku w zakresie jakości technicznej, przy jednoczesnym wysokim standardzie, jakości przestrzeni zycia i pracy spełnia znajdujący się w Dubaju, najwyższy budynek świata o nazwie Burj Khalifa. Budynek ten stanowi modelowy przyklad smart buildig obejmujący, oprocz jakossci technicznej, także jakość przestrzeni zycia i pracy człowieka. Przyjęte rozwiązania korelują wzajemnie czerpiąc z zasad towarzyszących innowacyjnemu połączeniu tego, co we współczesnym projektowaniu jest ekonomiczne, ekologiczne, elastyczne oraz estetyczne.

\section{Abstract}

The notion of 'smart building' was taking shape over the last twenty or thirty years of the past century. Initially, the term was used with respect to the advancement of the technologies installed in the building. With the development of information society and new forms of labour, new requirements appear with respect to buildings, which - apart from technological quality - extended to the qually or man's life and work."

The high requirements as regards the building's technological quality and high standard, quality of the space of life and work have all been met by the world's tallest building named Burj Khalifa, erected in Dubaii. The building is a model example of the applied correlate with one another, drawing upon the principles crucial for innovative combination of what is economical, ecological, flexible, and aesthetic in modern design trends.

\section{Stowa kluczowe:
nek przyszłości}

Keywords: smartbuliding, architecture, accessibility, ecology, energy efficiency, future building

Wysokie wymagania dla budynku w zakresie jakości technicznej, przy jednoczesnym wysokim standardzie, jakości przestrzeni życia i pracy spełnia znajdujący się w Dubaju budynek o nazwie Burj Khalifa. Od 2009 roku jest najwyższym budynkiem na świecie, jego wysokość sięga 828 metrów, liczy 160 pięter użytkowych, natomiast łącznie liczba pięter wraz z przestrzenią pomocniczą wynosi 206. Iglica Burj Khalifa jest widoczna nawet z odległości 95 kilometrów. Wieża przekracza kilka stref klimatycznych, a temperatura na wierzchołku budynku jest średnio o około $10^{\circ} \mathrm{C}$ niższa, niż na ziemi. Budynek można uznać za przykład inteligentnej architektury, tzw.

The high requirements as regards the building's the spercat lifealiy and high standard, quality of world's sallest building named Buri Khalifa, by the in Dubai. Since 2009, with a height of 828 metres, it has been the tallest building in the world. The tower features 160 useable storeys, the total number of storeys (including auxiliary space) being 206. up to 95 kilometres. The tower croses a distance matic zones; the temperature at the building's peak is lower by $10^{\circ} \mathrm{C}$, on average, than the one on the ground. Burj Khalifa can be termed a smart build-

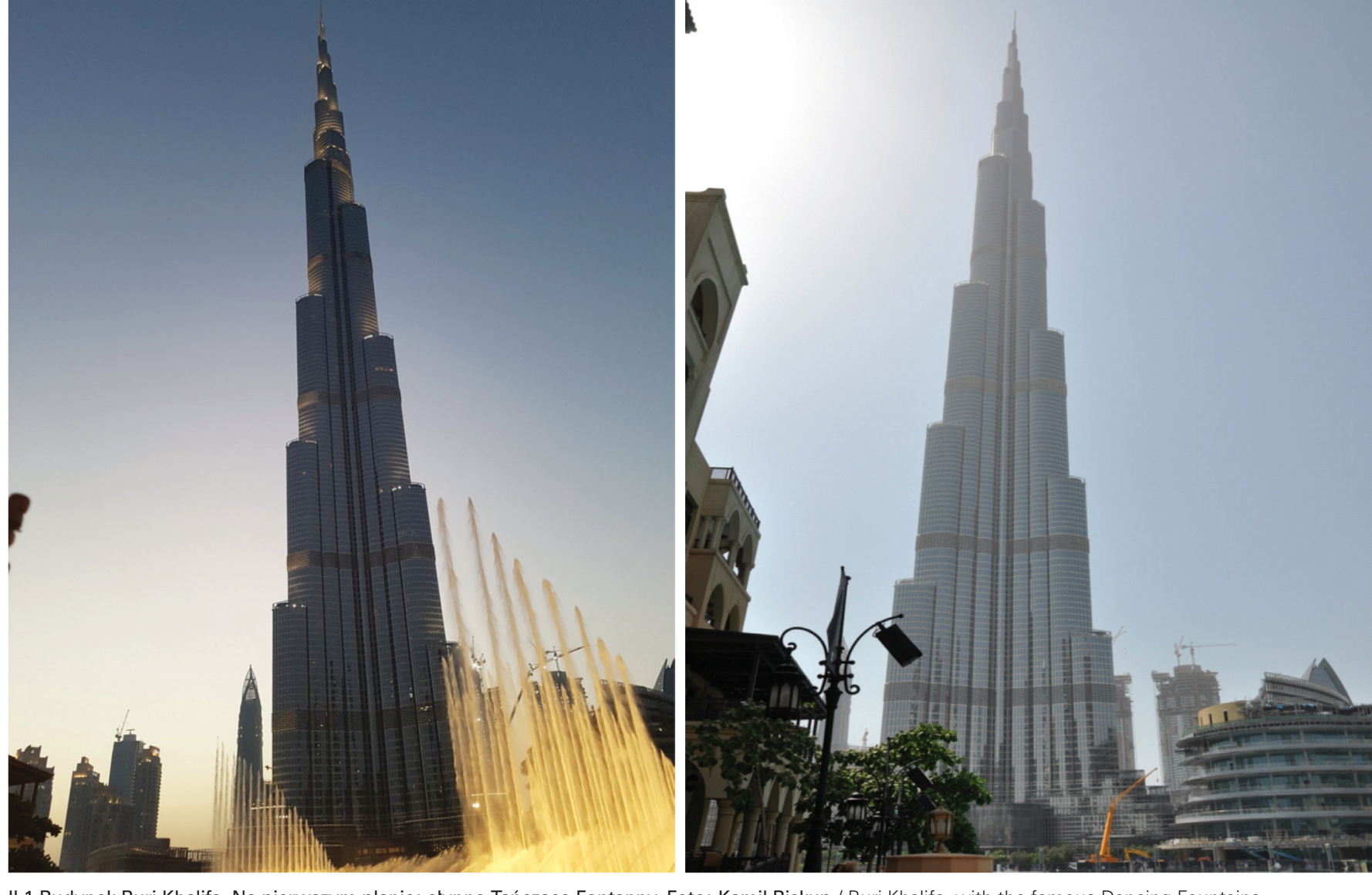

II.1 Budynek Burj Khalifa. Na pierwszym plate
in the foreground. (Photo by Kamil Biskup)

II. 2. Budynek Burj Khalifa. Foto: Kamil Biskup / Burj Khalifa, a general outside view. (Photo by K. Biskup)

smart building, wyznaczającej nowe kanony dla obowiązujących standardów w projektowaniu oraz uzytkowaniu obemującym zróżnicowane potrzeby. Burj Khalifa, liczạcy łącznie 330 tys. $\mathrm{m}^{2}$ powierzchni użytkowej jest jednocześnie niezwykłym dziełem sztuki łączącym w sobie kunszt wizji architektonicznej i inżynierii, mogạcym zaspokoić potrzeby mieszkaniowe i zwiazzane z funkcją biznesowa dla około 35 tys. osób. Buj Khalifa zlokalizowano na terenie centrum Dubaju, poddajac rewitalizacii cięzkie tereny pustynne.

Lokalizacja pozwolita na tatwe skomunikowanie z transportem Lubliczny co może ograniczá koniezność polszania sie wark kom klmatycznym podnoszac komfort zycia mieszkan-

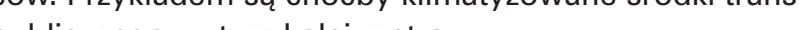

Nowoczesny budynek ma charakterystyczną zabudowę, inspirowana tradycyjnym dla Bliskiego Wschodu modelem występujące ow ne z bujną zielenią, elementy malej architektury, schody wewnętrzne prowadzące do glównego hollu, w ktorym znajduja się 24 windy transportuące mieszkańców do mieszkań na poszczegölnych kondygnacjach z jednoczesnym wykorzystaniem wewnątrz budynku. Zwarta zabudowa integruje się $z$ otoczeniem za pośrednictwem pieszych ciągów przechodzące przez przestrzeń publiczną, zawierającą skwerki z akcentem wody oraz cennej (zwłaszcza w tej części świata) zieleni. ing - a piece of 'smart' architecture that sets the new canons for the standards deemed prevalent in designing and use that encompasses diverse puposes and piece for art, sion and the sense of engineering. It can satisy the residential and business needs of some 35,000 people at a time. The tower is situated in the central area of Dubai, on the ground that previously

was a harsh and rough desert area.
The location has enabled easy connection with the public transport, which may limit the need to developed, addressing the hard climatic conditions and enhancing the comfort of its residents. One example is automated air-conditioning of the means of public transport, including the underground

The modern building in question features a peculiar architecture and developments of its surroundtions: the oval-shaped details and outlines, inner lanes with profuse greenery, elements of small architecture, internal stairs leading to the main hallway which contains twenty-four lifts transporting the residents to their apartments on the respective storeys, whilst also using the smart management of the optimisation of transport inside the build ing. The compact built-up design is integrated with set through the public space which features smal squares or park areas with water and greenery 
Potrzeby codzienne można zaspokoić na miejscu, bowiem strefie mieszk podnieść poziom życia i użytkowania środowiska mieszkalnego. W budynku znajduje się 900 luksusowych apartamentów mieszkaniowych, ale także pomieszczenia o funkcji handlowe i rekreacyjnej. 37 pięter przeznaczono na centrum handlowe w tym: 150 restauracji, 1200 sklepów, basen, meczet, lodowisko, czy też park gier tematycznych i ogromny KidZania wioskę zabaw dla dzieci.

Burj Khalifa zaprojektowano zgodnie z idea, w myśl której buBurj Khalfa zaprojektowano zgodnie z idea, w mysl ko rej buw trakcie procesu użytkowania. Środowisko naturalne Zjedw trakcie procesu użytkowania. Srodowisko naturalne Zjed-
noczonych Emiratów Arabskich to obszar zdominowany przez tereny pustynne oraz wysoką temperaturę sięgającą średnio $34^{\circ} \mathrm{C}$ w skali roku, a w sezonie letnim powyżej $40^{\circ} \mathrm{C}$; wpływa $34 \mathrm{C}$ w skal roku, a w sezonie lemim powyzej 40C; wplywa to na przegrzewanie się ponieszczon w budynku, co nega-

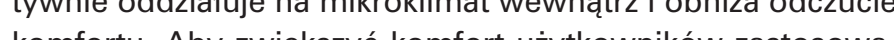
komfortu. Aby zwiększyc komfort uzytkownikow zastosowano innowacyjne rozwiązania w ścianach budynku. Zewnętrzne szklane sciany zostaly wykonane z fasady wykorystujące szklenie z powłoką odbijającą nadmiar promieni słonecznych. W budynkach o tak obszernej powierzchni użytkowej, mocno rozwiniętej infrastrukturze technicznej z wysokim stopniem skomplikowania instalacji wewnętrznych - odpowiedzialnych za jak najlepsze funkcjonowanie obiektu, potrzebny jest odpowiedzialny systemowy sposób zarządzania budynkiem. Aby zachować jak najlepszy standard użytkowania budynku ,stworzono inteligentny system wirtualnego zarządcy. System ten odpowiada za bezpieczeństwo oraz komfort użytkowania budynku. I tak na przykład: stwierdzając nadmiernie oddziaływanie promieni słonecznych w pomieszczeniu, automatyczne uruchamia system przesłaniania przestrzeni okiennych, co zapobiega zjawisku przegrzewania się wnętrza budynku. Inteligentny system zarządzania analizuje temperaturę pomieszczeń i samoczynnie optymalizuje ją, gdy przekroczy rekomendowane $23^{\circ} \mathrm{C}$. Zastosowano inteligentny system wymiany powietrza, gdy temperatura wewnatrz pomieszczen bedzie wieksza niz $23^{\circ} \mathrm{C}$. Okna czéci mieszkalnej wyposzia no $w$ dodatkowe przesłony antysłoneczne, które również zapobiegają przegrzewaniu się wnętrza pomieszczeń.

Dostarczane do pomieszczeń powietrze przechodzi proces obróbki termicznej przez schładzanie i filtracię. Dzięki temu inteligentne rozwiązania systemowe, zarządzające instalacjami budynku podnoszą komfort użytkowania poszczególnych stref budynku. Ponadto, zastosowane w komunikacji wewnętrznej rozwiązania są intuicyjne dla osób poruszających się wewnatr budynk. Buj Khalfa posiada klaki schodowe, służące między innymi, jako droga ewakuacji z budynku oraz system zintegrowanych 24 wind zlokalizowanych centralnie w głównym hollu budynku, służących do transportu pionowego, wewnętrznego. Wirtualny zarządca ustala prioryte pierwszensstwa dla wind optymalizując czas oczekiwania oraz odległość kabiny windy do potencjalnego przystanku na danej kondygnacji. Inteligentny system zarządzania pozwala na oszczędność czasu oczekujących na windy oraz minimalizuje koszty użytkowania i eksploatacji. System inteligentnych wind pozwala pokonać drogę 169 pięter w relatywnie krótkim work in the closest vicinity of its residential zone. The everyday needs can be met on the spot. The residential zone is accompanied with a number of and use of the residential environment. The of life and use of the residential environment. There are
900 luxury residential apartments, along with business/trade and recreation space. A shopping mal is laid out across thirty-seven storeys, including 150 restaurants, 1,200 retail outlets, a swimming pool, a mosque, a skating rink, a thematic games park, and more. There is an enormous
village for children, named KidZania.

Village for children, named KidZania.
Buri Khalifa has been designed in line with the idea whereby a building is to be virtually completely independent and self-sufficient when in use. The natural environment of the United Arab Emirates is dominated by desert areas and high temperatures, with the annual average of $34^{\circ} \mathrm{C}$ (above $40^{\circ} \mathrm{C}$ in the summer), with the resulting overheated space/
rooms inside the buildings and, consequently, adverse impact on the inside microclimate and compromised comfortableness. Hence, in order to ensure appropriate comfort for the users, innovative solutions have been applied within the building's walls. Its outer glazed walls form a façade com posed of areas of glazing covered with a coating
that protects excessive sunray exposure. A building with such an enormous useable area, A builddeveloped technical/technological infrastructure and highly complex internal installations and systems, responsible for the best possible functioning of the building, calls for a responsible systemic method of management. To ensure the utmos has been developed. The system is responsible for the security and comfort of use of the building. For example, in case excessive impact of sunrays is detected for a specified space or room inside the building, a window screening system of is au-
tomatically activated, thus preventing the effect tomatically activated, thus preventing the effect
of overheated inside space. The smart managing system analyses the temperatures of the building's spaces/rooms and self-actively optimises the temperature once the recommended level of $23^{\circ} \mathrm{C}$ is exceeded. There functions a smart air exchange system, which gets activated when the room's or
space's inside temperature has exceeded $23^{\circ} \mathrm{C}$. The windows in the residential section are furThe windows in the residential section are fur-
nished with solar covers, which additionally prevent inside spaces from overheating. The air supplied into the inner spaces is thermally processed by cooling and filtration. Consequently, the smart systemic solutions managing the build ing's installations/systems enhance the comfort of using the inside zones. Moreover, the solution applied for inside traffic work intuitively for thos ifa is equipped with stairwells designed, among other functions, as the evacuation route z budynku, and a system of 24 integrated lifts used for inside vertical transport purposes, with the ground-floor
entrances situated centrally inside the main hallentrances situated centrally inside the main hall-
way. The virtual manager sets the priority of use
for the lifts and optimises the waiting time and the for the lifts and optimises the waiting time and the
booth's distance to the stop to be potentially used on a given storey. The smart management system enables to save time for those waiting to be serve by the lift, and minimises the cost of use and op- czasie, wynoszącym nie więcej niż jedną minutę. Budynek nej, który w znaczny sposób wpływa na przekaz informacj sposób poruszania się oraz użytkownika w budynku. Każda $z$ wind posiada system wyświetlania informacji wizualnej za pomocą hologramu wewnatrz kabiny oraz na drzwiach zewnętrznych w hollu budynku. Wyświetlana informacja wskazuje piẹtro, na którym winda sie znajduje, potencjalny czas dotarcia na wskazana wondygnacie, temperature wewnatr dotarcia na wazana kewnatrz ina zewnąr bud. zarzadcy umożliwiaja sterowanie i ustalanie priorytetów inteligentnego systemu $w$ budynku.

Jednym z udogodnień, rzadko jeszcze stosowanym w budownictwie jest zastosowanie inteligentnego systemu czysz czenia elewacji. W budynku o tak niesamowitej wysokości jest to wreccz wskazane. Wirtualny zarządca analizując warunki pogodowe, sam ustala częstotliwość uruchamiania systemu składającego się z automatyzowanej sieci robotów czyszczacych elewacje budynku.

Burj Khalifa stanowi modelowy przykład smart buildig obejmujący, oprócz jakości technicznej, także jakość przestrzen zycia i pracy człowieka. Przyjęte rozwiązania korelują wzajemnie czerpiąc $z$ zasad towarzyszących innowacyjnem polazceniu tego, co ekonomicze, ekologiczne, oraz estetyczne. Nie bez znaczenia są tutaj czynniki lokalizacyjne. Promuje się transport publiczny, ktory jest alternatywą ekologicznego transportu. W tym celu wykorzystuje sie metro miejskie z klimatyzowanymi przystankami, dającymi ochłodę w tak surowym i gorącym klimacie. Kolej elektryczna wykorzystuje energię elektryczną częściowo pozyskaną z odnawialnych źródeł energii. Przystanki w bliskim otoczeniu budynku skomunikowane są z budynkiem przez zamknięte i klimatyzowane trakty nadziemne ciągów pieszych.

Zastosowanie odnawialnych źródeł energii neutralnych pod Zas inteligentnych b . est nie mniej istotny od komfortu środowiska naturalnego. Występujące instalacje pozyskują energię elektryczną z ener-

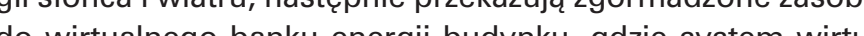

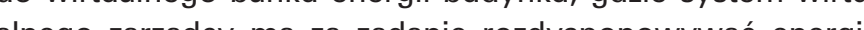

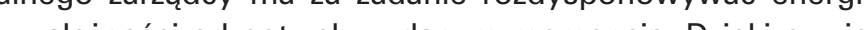
w zależnosci od potzeb w danym momencie. Dzięki przyje tym rozw ązaniom inteligentny system wirtualnego zarządcy bezpostednio zarądza infrastrukturą budynku w sposób podnoszący komfort uzytkowania budynku, jak również prowadzi do maksymalnej optymalizacji kosztów z tym związanych. System przechwytuje informacje, w której części obiekt należy ograniczyć zużycie energii elektryczne, cieplnej, czy eź zwiększyć wy dajnośc instalacji wentylacji mechaniczne bądź klimatyzacji. System nie tylko ogranicza czy też zwiększ wydajnośc instalacji bytowych w budynku, lecz nieustannie wydawnza ich stan techniczny i stopien zuzycia. W przypadk jakiejkolwiek awarii automatycznie lokalizuje miejsce, przyczynę uszkodzeń i w trybie automatycznym wzywa serwis wskazując zakres i cel naprawy. Wirtualny zarządca nie tylko odbiera informacje, w której części budynku należy dokonac eration. The smart lift system allows to travel the 169-storey route in a relatively short time of ap prox. 1 minute maximum. There is also a smart the communication of information the methac moving around the building's inner spaces and using its features. Each lift is equipped with visua information display system with use of a hologram provided inside the booth and outside door in the hallway. The user is advised as to the storey the lift is on at the given moment, the potential time in peratures inside and outside the building as well as the home and international headline news. The virtually limitless potential of the virtual manager enable to control and define the priorities for the smart system operating inside the building.

One peculiar facility, not yet common in construction design, is a smart elevation cleaning systebuilding this high. On analysis the weather conditions, the virtual manager defines the frequency at which the system is activated. In itself, the system in question consists of an automated network of robots cleaning the building's elevation.

Burj Khalifa is a model specimen of the smart build ing concept - one that essentially encompasses the 'quality of man's life and work'. The solution employed in its design inter-correlate and draw upon the principles crucial for innovative combination of what is economical, ecological, flexible, and aesthetic in modern design trends. The locationransport is promoted as a solution alterntive to the 'green' transport. To this end, the city underground (metro) network is used, wits its air-conditioned stops allowing the passengers to refresh in the prevalently harsh and hot climate conditions. generated by renewable sources. The train stops in he close vicinity of Burj Khalifa are connected with the building via the closed air-conditioned abovegThe tracts of pedestrian precincts.

The use of renewable sources of energy is part, as for as emissions of exhaustive gases is concerned. comfort of the environmental comfort. The systems install tions employed consume solar and wind energy and then convey the amassed resources to the builsmart manager system is tasked with distributing The power depending on the need of the moment The smart manager system is capable of directl/y enhances the comfort of us the building and thaximise the related expense. The system captures the information as to which part or section of the building needs to have electricity/heat consumption reduced, or where exactly to increase the output of The system's task is not only to increares the throughput of the utility systems: it constantly checks for the technical condition and wear-and tear of the latter. In case of any failure, the place and the cause of damage are spotted immediately,
and automatically calls for a service team, defining 
optymalizacji przyjętych rozwiązań, lecz również jest w stanie przewidzieć, w której części obiektu należy zwiększyć zapotrzebowanie infrastruktury technicznej w celu zwiększenia komfortu użytkowników. Inteligentne zarządzanie windami przyczynia się do optymalizacji kosztów użytkowania i eksploatacji budynku oraz zniesienia barier czasowych związanych z nadmiernym oczekiwaniem na przybycie. Budynek wyposażony jest w instalację solarną wykorzystującą panele fotowoltaiczne oraz instalację zbierającą i magazynującą szarą wodę pochodzącą z opadów deszczu. W tym środowisku woda jest cennym surowcem, dlatego też zastosowany inteligentny system odzyskiwania wody opadowej pozwala zgromadzoną szarą wodę oczyścić w złożonym procesie recyklingu i ponownie wykorzystać ją na potrzeby związane z funkcjonowaniem budynku. Zastosowano pasywną wentylację budynku wykorzystując samonastawną nasadę komina, która ustawia się aerodynamicznie przeciwnie do kierunku wiatru. Ściany budynku są izolowane próżniowo, a okna wykonane z wielkogabarytowych fasad szklanych posiadających szyby z powłoką odbijającą nadmierną ilość promieni słonecznych, w której przestrzeń międzyszybowa wypełniona została wysokiej, jakości gazem pozwalającym ograniczyć przenikanie energii cieplnej przez przegrodę. Przyjęte rozwiązanie zapobiegają nadmiernemu przegrzewaniu się pomieszczeń wewnątrz budynku narażonego na nadmierne oddziaływanie promieni słonecznych. Zastosowane innowacyjne rozwiązania technologiczne podnoszą komfort życia użytkownika, podkreślając jednocześnie inteligentne rozwiązania architektoniczne budynku. Na terenie zespołu budynku Burj Khalifa znajduje się parking liczący ponad 10.000 miejsc postojowych. Jest to liczba znacznie powyżej standardów przyjętych w krajach Unii Europejskiej. Parkingi wyposażono w intuicyjny, inteligentny system naprowadzający kierowcę do najbliższego, wolnego miejsca parkingowego. Przy tak niespotykanej ilości miejsc postojowych zlokalizowanych w jednym miejscu chwila nieuwagi może spowodować gigantyczne korki wewnątrz wielopoziomowego parkingu oraz głównej ulicy, na którą wyjeżdża się z obiektu.

Analizując przyjęte rozwiązania architektoniczne i techniczne, wykorzystanie wysokiej jakości technologii, nie można nie odnieść wrażenia, iż budynek pokazuje możliwości, które aktualnie stają się coraz bardziej pożądane w procesie inwestycyjnym i użytkowym. W przypadku Burj Khalifa idea smartbulding komponuje się z kompleksowym podejściem do zagadnienia maksymalizacji rozwiązań technicznych, które optymalnie podniosą komfort użytkowania.

\section{PRZYPIS}

Pod. red. E. Niezabitowska. Budynek inteligentny. Wydawnictwo Politechniki Śląskiej, Gliwice 2014

\section{LITERATURA}

[1] Główny serwis w Polsce o systemie inteligentnego domu KNX/EIB - www. knx.pl.

[2] System inteligentnego domu - www.haus-bau-system.de.

[3] Inteligentny dom - www.smartech.pl.

[4] Inteligentny Budynek SMART - www.s3art.com. the purpose and scope of the repair. Not only does the virtual manager receive information on which part/section of the building needs to get an its existing solutions optimised but it can predict where in particular the techn(olog)ical infrastructure needs getting its serviceable needs increased in order to enhance user comfort. Smart management of the lifts implies optimised cost of the building's use and operation, and releases time barriers related to excessive waiting time.

There is a solar system provided based on photovoltaic panels and an installation that collects and stores grey rainwater. Water is a valuable (raw) material, or consumable, in this specific environment, and hence the smart rainwater regaining system applied enables to purify the amassed grey water though a complex recycling process and then reuse it to meet the needs related to the building's functioning. A passive ventilation system was employed, with use of self-adjustable chimneystack base, which aerodynamically assumes the position opposite to the wind. The building's walls are vacuum insulated; the windows are made of large-size glazed facades with panes covered by a coating reflecting excessive sunrays, with the inter-pane space filled with quality gas enabling to reduce penetration of heat energy through the divider. These solutions prevent overheating of inside spaces in the building that is otherwise exposed to excessive sunray impact. The innovative technologies applied enhance the comfortableness of the user's life, whilst highlighting the smart architectural solutions employed.

The Burj Khalifa complex area includes a parking lot with more than 10,000 plots available - much in excess of the EU standard. The parking area is equipped with an intuitive smart system that 'drives' the driver towards the nearest parking plot available. With such an incredibly large number of plots concentrated in one place, a moment of inattention might cause enormous traffic jams inside the multistorey garage and in the central street into which the cars flow when leaving the facility area.

Given the assumed and delivered architectural and techn(olog)ical solutions, and use of higestquality technologies, one immediately realises that the project under discussion displays an enormous potential that is becoming increasingly in demand for the investment and use/consumption processes. In the special Burj Khalifa case, the smart building idea has coincided with a comprehensive approach toward maximisation of techn(olog)ical solutions that optimally increase the comfort of use.

\section{ENDNOTE}

Pod. red. E. Niezabitowska. Budynek inteligentny. Wydawnictwo Politechniki Śląskiej, Gliwice 2014

\section{BIBLIOGRAPHY}

[1] Główny serwis w Polsce o systemie inteligentnego domu KNX/EIB - www.knx.pl.

[2] System inteligentnego domu - www.haus-bau-system.de.

[3] Inteligentny dom - www.smartech.pl.

[4] Inteligentny Budynek SMART - www.s3art.com. 